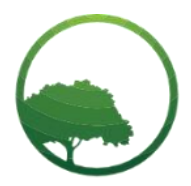

Research in Business \& Social Science

IJRBS VOL 10 NO 6 ISSN: 2147-4478

\title{
The influence factors of the complementary level of financial and tax aggressiveness in Indonesia

\author{
Salsabila Anggiani Amriza ${ }^{(a)}$ (D) Nurul Aisyah Rachmawati ${ }^{(b) *}$ \\ ${ }^{(a, b)}$ Accounting Department, Faculty of Economics and Business, Universitas Trilogi, Jl. TMP Kalibata No. 1, Jakarta, Indonesia
}

\author{
ARTICLE INFO \\ Article history: \\ Received 13 August 2021 \\ Received in rev. form 22 Sep. 2021 \\ Accepted 23 Sept 2021 \\ Keywords: \\ Financial Reporting Aggressiveness, \\ Tax Aggressiveness, Financial \\ Constraint, Audit Quality, \\ Complementary Level of Financial \\ and Tax Aggressiveness \\ JEL Classification: \\ G32
}

\begin{abstract}
A B S T R A C T
This research focus to investigate the effect of audit quality and financial constraint on the complementary level of financial and tax reporting aggressiveness. This research uses binary logistic regression to investigate the effect of audit quality and financial constraint on the complementary level of financial and tax reporting aggressiveness with a sample of 147 manufacturing companies listed on the Indonesia Stock Exchange (IDX) in 2017-2019. This research found that companies with good audit quality have a complementary level of financial and tax reporting aggressiveness that tends to be below. Also, companies that face financial constraints have a higher complementary level of financial reporting and tax aggressiveness. This study presents empirical evidence that supports the view of audit quality and financial constraint's impact on the complementary level of financial and tax aggressiveness. Although there are many studies that discuss the relationship between financial and tax aggressiveness, there are still few studies that contribute to examine the determinants of the complementary level of financial and tax reporting aggressiveness in Indonesia.
\end{abstract}

(C) 2021 by the authors. Licensee SSBFNET, Istanbul, Turkey. This article is an open access article distributed under the terms and conditions of the Creative Commons Attribution (CC BY) license (http://creativecommons.org/licenses/by/4.0/).

\section{Introduction}

Firms as the taxpayers tend to see tax as a deduction from the income generated, they tend to engage in tax aggressiveness to minimize the tax paid by the firm (Chen et al., 2010). However, the practice of tax aggressiveness can lessen the investment made by investors in the company. To maintain the company's reputation, they tend to be aggressive in financial reporting. Financial reporting aggressiveness is defined as an act of upward (positive) earnings management (Frank et al., 2009; Rachmawati et al., 2020), in which companies tend to increase their profits to attracting investors' attention to invest in the company and maintaining their reputation.

Based on the cost $\&$ benefit analysis, the company will be considering the costs and benefits as the consequence when deciding to engage in concurrent financial and tax reporting aggressiveness (Rachmawati et al., 2019). In this study, size of the audit firms is the proxy for cost. According to Annisa and Kurniasih (2012), Big Four audit firms is believed to have a higher audit quality and shows the actual condition of its client when auditing financial statements compared to companies audited by non-Big Four audit firms. Investors have the perception to trust audit firms with a brand name (Big Four) more than other auditors (Sanjaya, 2017). The level of risk detection that will be faced by the company will be higher when the company has good audit quality.

Furthermore, we chose financial constraint as the proxy for benefit. Companies that experiencing financial constraint will get benefits, such as minimize the taxes paid by the company (Lyon, 2014) when they carry out the financial reporting and tax aggressiveness at the same time. A higher complementary level of financial and tax aggressiveness indicates uncertainty and fraud in reporting which causes a higher risk (Rachmawati et al., 2019). The company still need to consider the risk detection that they will face when carry out financial and tax aggressiveness.

* Corresponding author. ORCID ID: 0000-0002-7482-0445

(C) 2021 by the authors. Hosting by SSBFNET. Peer review under responsibility of Center for Strategic Studies in Business and Finance. https://doi.org/10.20525/ijrbs.v10i6.1317 
Using a sample of manufacturing companies listed on the Indonesia Stock Exchange (BEI) from 2017-2019, this study predicts and finds that firms with good audit quality tend to have a lower complementary level of financial and tax aggressiveness. Furthermore, firms with financial constraints tend to have a high complementary level of financial reporting and tax aggressiveness.

The remainder of this paper is structured as follows; Section 2 describes literature review and hypothesis development, Section 3 describes the research methodology, Section 4 presents the research results and discussion of the results, Section 5 presents the conclusions of the research.

\section{Literature Review}

According to Bulow et al., (1985), the complementary strategy of financial and tax aggressiveness is a reporting strategy that does not lessen the benefits of other reporting strategies of company and complements mutually. Theoretically, managers will face a tradeoff condition when aggressively conducting both financial reporting and tax. The tax paid by the company will be higher if the manager decides to do earnings management which will increase the company's profit. Conversely, when manager engage in tax aggressiveness to minimize the tax paid by company, the earnings on the financial report will be smaller which can reduce the company's reputation in the eyes of investors. However, practically the trade-off does not always happen when managers decide to aggressively report financial reporting and tax at the same time. A higher risk will arise as a result of fraud in reporting, which can indicate the higher complementary level of financial and tax reporting aggressiveness (Rachmawati et al., 2019).

\section{Audit Quality}

Audit quality is defined as the various opportunities for the auditor to find errors or fraud that occurred when auditing the client's financial statements (Dewi \& Jati, 2014). In this research, audit quality is measured by audit firm size, namely Big Four and non-Big Four. The Big Four auditors are considered to have better audit quality than the non-Big Four for reasons of ability to maintain the reputation of the audit firm, having greater potential resources that can be used for recruitment, training, and technology (Mardiyaningsih, 2020). Investors have the perception to trust audit firms with a brand name (Big Four) more than other auditors (Sanjaya, 2017).

Rusmin (2010) states that the earnings management action on the audit results conducted by Big Four auditors is lower than the nonBig Four. A high quality audit has a role as a prevention of earnings management because if the fraud of financial reporting is detected and revealed, the management's reputation will be destroyed and decrease the company's value to investors (Christiani and Nugrahanti, 2014). Herusetya (2012) proves the negative effect of the audit quality of the big four audit firms on earnings management behavior while maintaining reputation protection. Khoirunnisa et al. (2015) and Feranika (2016) state that the audit quality affects the company's tax aggressive behavior. A good audit quality will be able to suppress the company's tax aggressive behaviour because the auditors are able to maintain their integrity in the implementation of audits so that the company's efforts to reduce tax burden have been disclosed to the public. Firms that are being audited by the Big Four auditors will consider the level of risk detection is higher than the benefits that will be obtained.

Based on these arguments, we concluded that the effect of audit quality on the complementary level of financial and tax aggressiveness is negative. Firms with a good audit quality tend to have a low complementary level of financial and tax aggressiveness. The hypothesis is thus formally stated as follows:

H1: Firms with good audit quality tend to have a lower complementary level of financial and tax aggressiveness.

\section{Financial Constraint}

The company is said to have financial constraints when there is limited capital obtained by the company as a source of funds for investment. According to Kellogg and Kellogg (1991), firms with financial constraint usually have limited internal funding. Companies will get benefits when conducting concurrent financial reporting and tax aggressiveness (Rachmawati et al., 2019). Firms that report losses on their financial statements will find it difficult to get loans from banks and cannot issue stocks or bonds at adequate prices. Then the manager will have the tendency to make the company's value good for the capital market by increasing revenue by engaging in financial reporting aggressiveness (Koh and Lee, 2015), and will increase tax savings through tax avoidance (Bayuaji, and Firmansyah, 2016).

Based on these arguments, companies with financial constraints will tend to choose complementary strategy rather than substitution strategy when conducting concurrent financial and tax aggressiveness. Company tend to have a higher complementary level of financial and tax aggressiveness because of the benefit they will obtain. The hypothesis is thus formally stated as follows:

H2: Firms with financial constraint tend to have a higher complementary level of financial and tax aggressiveness.

\section{Research \& Methodology}

\section{Sample Selection}

The population of this study are manufacturing companies that publish their financial reports on the Indonesia Stock Exchange (IDX) over 3 years, from 2017 to 2019 . The sampling technique used in this study is purposive sampling method. 
The criteria chosen in sampling were:

i. Manufacturing firms listed on the Indonesia Stock Exchange (IDX) from 2017 to 2019 and were not delisted during the research period.

ii. Manufacturing firm that report financial statements or annual reports in a row during the years of research from 20172019.

iii. Manufacturing firms that have complete data related to the variables used in this study from 2017 until 2019.

Measuring the complementary level of financial and tax aggressiveness.

The complementary level of financial and tax aggressiveness (COMP) in this study is measured by a measurement developed by Rachmawati et al. (2019). COMP is measured in several steps. First, the measurement of the financial reporting aggressiveness with the Modified-Jones Model, as assessed using the equation (1) as follows:

$$
\operatorname{TACC}_{i t}=\alpha_{0}+\alpha_{1}\left(\Delta R E V_{i t}-\triangle R E C_{i t}\right)+\alpha_{2} P P E_{i t}+\varepsilon_{i t}
$$

where, TACC $\mathrm{it}_{\mathrm{it}}$ is the total accrual of firm $i$ in year $t . \Delta R E V_{i t}$ is the change in firm revenue between year $t-1$ and $t . \Delta R E C_{i t}$ is the change in accounts receivable of firm $i$ between year $t-1$ and $\mathrm{t}$. PPE $\mathrm{it}_{\mathrm{it}}$ is the fixed assets of firm $i$ firm in year $t$. $\varepsilon_{i t}$ is the regression residue indicating the discretionary accruals (DFIN) of firm $i$ in year $t$. All of the above variables are scaled by total assets in year $t$ 1 .

Second, tax aggressiveness is measured using discretionary permanent difference (DTAX) following Frank et al., (2009) developed by Rachmawati et al., (2019) using equation (2) as follows:

$$
\text { PERMDIFF }_{i t}=\alpha_{0}+\alpha_{1} \text { INTANG }_{i t}+\alpha_{2} \operatorname{UNCON}_{i t}+\alpha_{3} \Delta N O L_{i t}+\alpha_{4} L_{A G P E R M_{i t}}+\varepsilon_{i t}
$$

where, PERMDIFF $F_{i t}$ is permanent differences firm $i$ in year $t . I N T A N G_{i t}$ is intangible asset (goodwill) of firm $i$ in year $t$. UNCON $i t$ is the consolidated profit (loss) of company $i$ in year $t . \triangle N O L_{i t}$ is the change in net operating loss carryforward firm i between year $t-1$ and $t$. LAGPERM $i t$ is the lag value of permanent difference firm $i$ in year $t$. $\varepsilon_{i t}$ is the regression residuals which indicates a permanent difference discretionary (DTAX) firm i in year $\mathrm{t}$. All of variables are scaled by total assets in year $t-1$. The greater the DTAX value, the greater the company's tax aggressiveness.

Afterwards, the DFIN and DTAX scores were classified into quintiles according to year into 4 groups. First, firms that tend to have a high complementary level of financial and tax aggressiveness are in the quintile combination group with a positive DFIN and DTAX value. Second, companies that tend to have a low complementary level of financial and tax aggressiveness are in the quintile combination group with a positive DFIN or DTAX value. Which means that only one value has a positive or negative sign on the second quintile combination group. For the third amd fourth quintile combination group, the companies in this group are removed from sample. The reasons are; (1) the value of DFIN and / or DTAX are positive or negative (inconsistent for the whole combination group) that causes the relationship of DTAX and DFIN is ambiguous, and (2) DFIN and DTAX have a negative values, which means the companies does not tend to engage in conducting concurrent financial and tax aggressiveness. The quintile combination of DTAX and DFIN are carried out by classifying the results of DTAX and DFIN with quintiles ranging from one (firms with a low complementary level of financial and tax aggressiveness) to five (firms with a high complementary level of financial and tax aggressiveness).

Finally, COMP is a variable dummy equal to 1 if the complementary level of financial and tax aggressiveness for firm $i$ in year $t$ is high and equal to 0 if the complementary level of financial and tax aggressiveness for company $i$ in year $t$ is low.

\section{Measuring audit quality}

Audit quality is a dummy variable measured by the size of audit firms, equal to 1 if the company audited by the Big Four audit firm, namely Deloitte Touche Tohmatsu, Ernst \& Young (E\&Y), Price Waterhouse Cooper (PWC), and KPMG. And equal to 0 if the firms audited by the non-Big Four audit firms.

\section{Measuring financial constraint}

Company's financial constraint is measured by combining three measures of financial constraints using confirmatory factor analysis, namely net debt ratio, interest coverage ratio, and dividend payout ratio. We used a new measurement developed by Rachmawati et al (2019). The first measure is net debt ratio to present the companies ability to pay its liabilities by dividing the total long term debt and short term debt with the total assets of company $i$ in year.

The second measure is interest coverage ratio. The interest coverage ratio is used to present the company's ability to pay their obligations. Company with high financial costs tend to experience financial constraints compared to company with low financial costs, which means companies with low interest coverage ratios tend to face financial constraints than firms with high interest coverage ratios. Due to negative relationship between financial constraint and interest coverage ratio, the result of interest coverage is multiplied by -1 . Interest coverage ratio is measured by dividing earnings before interest and tax (EBIT) by interest expense. 
The third measure is dividend payout ratio, used to show the company's ability to pay dividends to shareholders. Firms that are unable to distribute revenues to shareholders are more likely to face financial constraints than firms that are able to distribute revenues. Due to negative relationship between financial constraint and divudend payout ratio, the result is multiplied by -1 . Dividend payout ratio is measured by dividing dividends per share (DPS) with earnings per share (EPS).

\section{Measurement of Control Variables}

This study uses company size and sales growth as the control variables. According to Kurniasih and Sri (2012), company size is a value that presents the size of the company by its assets. Assets owned by a company are related to the size of the company, the bigger the company means the greater total assets the company owns. Company size is measured using the normal logarithm of total assets (Hantono, 2016). The second control variable is sales growth. Sales growth presents the development of firm's sales from year to year (Budiman and Setiyono, 2012). Sales growth can be measured by calculating the end sales of the period in year $t$ minus the end sales of the previous year divided by the end sales of the previous year. (Swingly and Sukartha, 2015).

\section{Regression Model}

This study aims to examine the effect of audit quality $\left(\mathrm{KA}_{\mathrm{it}}\right)$, financial constraints (FINCON $\mathrm{Fit}_{\mathrm{it}}$, and control variables $\left(\mathrm{CONTROL}_{\mathrm{it}}\right)$ consisting of firm size $\left(\mathrm{SIZE}_{\mathrm{it}}\right)$ and sales growth $\left(\mathrm{GROWTH}_{\mathrm{it})}\right)$ to the complementary level of financial and tax aggressiveness (COMP ${ }_{i t}$ ). This study uses a binary logistic model because the dependent variable is a dummy variable. The measurement model used by Rachmawati et al., (2019) to measure the complementary level of financial and tax aggressiveness with equation (3) as follows:

$$
\operatorname{Pr}\left(\operatorname{COMP}_{i t}=1\right)=\frac{e_{0}^{\alpha}+\alpha_{1} \text { KA }_{i t}+\alpha_{2} \text { FINCON }_{i t}+\alpha_{k} \operatorname{CONTROL}_{k}+\varepsilon_{i t}}{1+e_{0}^{\alpha}+\alpha_{1} \text { KA }_{i t}+\alpha_{2} \text { FINCON }_{i t}+\alpha_{k} \operatorname{CONTROL~}_{k}+\varepsilon_{i t}}
$$

\section{Empirical Results and Discussion}

Descriptive Statistics

Table 1 presents the results of descriptive statistics for 156 observations. Based on table 1, there are 71 observations (45.51\%) tend to have a high complementary level of financial and tax aggressiveness, and the remaining 85 observations (54.49\%) tend to have a low complementary level of financial and tax reporting aggressiveness. For the KA (Audit Quality) variable, 65 observations were audited by the Big Four audit firms which indicated a good audit quality, and as many as 91 companies (58.33\%) were audited by the non-Big Four audit firms which indicated a low audit quality.

Table 1: Descriptive Statistics

\begin{tabular}{|c|c|c|c|c|c|c|}
\hline Variable & Obs & Mean & Median & Minimum & Maximum & SD \\
\hline FINCON $_{\text {it }}$ & 156 & -0.09 & -0.08 & -1.17 & 0.72 & 0.25 \\
\hline SIZE $_{\text {it }}$ & 156 & 28.59 & 28.49 & 25.22 & 31.65 & 1.34 \\
\hline \multirow[t]{3}{*}{ GROWTH $_{\text {it }}$} & 156 & 0.06 & 0.05 & -0.90 & 0.65 & 0.17 \\
\hline & & \multicolumn{3}{|c|}{ Dummy = 1} & \multicolumn{2}{|l|}{ Dummy $=0$} \\
\hline & & $\mathrm{N}$ & $\%$ & & $\mathrm{~N}$ & $\%$ \\
\hline $\mathrm{COMP}_{i t}$ & & 71 & $45.51 \%$ & & 85 & $54.49 \%$ \\
\hline $\mathrm{KA}_{\mathrm{it}}$ & & 65 & $41.67 \%$ & & 91 & $58.33 \%$ \\
\hline
\end{tabular}

The mean value of FINCON is -0.09. Negative sign on the mean value of FINCON variable shows that on average the firms in the sample do not experience financial constraint. The greater the FINCON value, the more it indicates the company is experiencing financial constraint. The maximum value of FINCON variable is 0.72 presents the firms that experience financial constraints and the minimum value of FINCON variable is -1.17 presents the firms that do not experience financial constraints.

Furthermore, the mean values of SIZE and GROWTH variables are 28.59 and 0.06 respectively. It indicates that on average the company has a large company size and experiences sales growth. The sample data for the SIZE variable did not vary, this was indicated by the SIZE standard deviation value of 1.34 which is smaller than the mean value of 28.59 . The sample data for the GROWTH variable varies, this was indicated by the SIZE standard deviation value of 0.17 , which is greater than the mean value of 0.06 .

\section{Correlation Coefficient}

The correlation coefficient determines and investigates the relationship between the dependent variable and the independent variables. The correlation coefficient in this study uses the Pearson correlation. The correlation coefficient can also show multicollinearity problems between independent variable to another independent variable. It is said that there is a multicollinearity problem if the coefficient value between independent variables is more than 0.08 (Ulfa and Juliansyah, 2018). The results of the Pearson correlation are presented in Table 2 following: 
Table 2: Pearson Correlation

\begin{tabular}{lllllll}
\hline No. & Variable & $\mathbf{1}$ & $\mathbf{2}$ & $\mathbf{3}$ & $\mathbf{4}$ & $\mathbf{5}$ \\
\hline 1 & COMP $_{\text {it }}$ & 1,00 & & & & \\
\hline 2 & KA $_{\text {it }}$ & -0.20 & 1.00 & & & \\
\hline 3 & FINCON $_{i t}$ & 0.15 & 0.07 & 1.00 & 1.00 & 1.00 \\
\hline 4 & SIZE $_{\text {it }}$ & -0.15 & 0.46 & 0.15 & 0.05 & $-0,08$ \\
\hline 5 & GROWTH $_{\text {it }}$ & 0.18 & -0.00 & & \\
\hline
\end{tabular}

Table 2 shows the audit quality variable $\left(\mathrm{KA}_{\mathrm{it}}\right)$ has a negative and significant correlation at the $5 \%$ level with the complementary level of financial and tax aggressiveness (COMP ${ }_{i t}$ ). This result is consistent with $\mathrm{H}_{1}$, firms with a good audit quality tend to engage in a low complementary level of financial and tax aggressiveness. Financial constraints (FINCON $\mathrm{it}_{\mathrm{it}}$ ) have a positive and significant correlation at the 5\% level with the complementary level of financial and tax aggressiveness (COMP $\mathrm{it}$ ). This result is consistent with $\mathrm{H}_{2}$, firms with financial constraint tend to engage in a high complementary level of financial and tax aggressiveness.

The control variable firm size (SIZEit) has a negative and significant correlation at the $10 \%$ level with the complementary level of financial and tax aggressiveness $\left(\mathrm{COMP}_{\mathrm{it}}\right)$. Sales growth $\left(\mathrm{GROWTH}_{\mathrm{it}}\right)$ has a positive and significant correlation at the $5 \%$ level with the complementary level of financial and tax aggressiveness (COMP $\left.{ }_{i t}\right)$. Table 2 also shows that there is no multicollinearity problem between independent variable to another independent variable because there is no correlation coefficient value between independent variables that exceeds 0.8 .

\section{Results}

The dependent variable in this study COMP it is a dummy variable, equal to 1 if firms engage in a high complementary level of financial and tax aggressiveness and equal to 0 otherwise. The hypothesis test is carried out using the binary logistic regression test. The results of the logistic regression are presented in Table 3 following:

Table 3: Logistic regression determines the complementary level of financial and tax aggressiveness.

\begin{tabular}{|c|c|c|c|c|c|c|}
\hline \multirow[b]{2}{*}{ Variable } & \multirow[b]{2}{*}{$\operatorname{Exp}$} & \multicolumn{5}{|c|}{ Dependent Variable: COMP $_{\text {it }}$} \\
\hline & & Coefficient & $\mathbf{Z}$ & $\mathbf{P}>|\mathbf{z}|$ & Significance & $\begin{array}{l}\text { Effect } \\
\text { Margin }\end{array}$ \\
\hline $\mathrm{KA}_{\mathrm{it}}$ & $\mathrm{H}_{1}(-)$ & -0.70 & -3.58 & 0.04 & $* *$ & -0.17 \\
\hline FINCON $_{\text {it }}$ & $\mathrm{H}_{2}(+)$ & 1.86 & 4.98 & 0.00 & $* * *$ & 0.46 \\
\hline SIZE $_{\text {it }}$ & & -0.20 & -2.70 & 0.09 & $*$ & -0.05 \\
\hline GROWTH $_{\text {it }}$ & & 2.78 & 4.96 & 0.00 & $* * *$ & 0.68 \\
\hline Cons & & 5.82 & 2.78 & 0.08 & & \\
\hline LR chi ${ }^{2}$ & 19,53 & & & & & \\
\hline Prob $>$ chi $^{2}$ & $0.00 * * *$ & & & & & \\
\hline Pseudo $\mathbf{R}^{2}$ & $9.08 \%$ & & & & & \\
\hline $\mathbf{N}$ & 156 & & & & & \\
\hline
\end{tabular}

Based on table 3, it shows that the coefficient of $\mathrm{KA}_{\mathrm{it}}$ is negative and significant at the $5 \%$ level and has a marginal effect value of 0.17 . These results indicate that when the firm has a good audit quality, the company's tendency to act aggressively in financial and tax reporting will simultaneously decrease by $17 \%$. These results are also consistent with $\mathrm{H}_{1}$, where firms with a good audit quality tend to engage in a low complementary level of financial and tax aggressiveness. When the firm has good audit quality, the detection risk will be face by the firm is higher. Good audit quality has a role as a deterrent to the financial and tax aggressiveness because if these actions are detected and revealed it can damage the firm's reputation in the eyes of investors and the public (Christiani and Nugrahanti, 2014). This result consist with Herusetya (2012), which states that the audit quality of Big Four audit firms has a negative effect on earnings management behavior while maintaining reputation protection. Also with the researches of Fadhilah (2014), Sandy and Lukviarman (2015), and Feranika et al. (2016), they state that the audit quality has a negative effect on corporate tax aggressive behavior.

The coefficient of FINCON ${ }_{i t}$ is positive and significant at the $1 \%$ level. The marginal effect of the FINCON variable is 0.46 . These results indicate when a company's financial constraint increases, the tendency to act aggressively in financial and tax reporting will simultaneously increase by $46 \%$. These results are also consistent with $\mathrm{H}_{2}$, indicates where firms with financial constraints tend to engage in a high complementary level of financial and tax aggressiveness. Firms facing financial constraints will get benefits if they conduct the concurrent financial and tax aggressiveness. These results are in line with research conducted by Rachmawati et al. (2019), which states that financial constraint is positive and significant to the complementary level of financial and tax aggressiveness. 
Companies tend to have a higher complementary level of financial and tax aggressiveness because of the greater benefits they will get when conducting financial and tax aggressiveness at the same time.

The coefficient of control variable SIZE is negatively and significant at the $10 \%$ level. The marginal effect value of the SIZE is 0.05. These results indicate when the size of the company increases, the tendency to act aggressively in financial and tax will simultaneously decrease by $50 \%$. This indicates that big size company tend to engage in a low complementary level of financial and tax aggressiveness. A big size company tend to not engage in upward earnings management. The big size company means having large assets that will become an attraction for investors. The total assets owned by the company can be used as collateral by investors if the company experience a loss. This result is in accordance with the research of Herlambang and Darsono (2015) which states that company's size has a significant negative effect on earnings management. This result is also in accordance with the research of Leksono et. al (2019), where firm size partially has a negative relationship to tax aggressiveness because big firms will be more monitored and get more attention from the government and the public (Herlambang and Darsono, 2015). However, the results of this study contradict the research of Rachmawati et al. (2019) which gives the results that firm size is not significant on the complementary level of financial and tax aggressiveness.

The coefficient of control variable GROWTH is positive and significant at the $1 \%$ level. The marginal value of the GROWTH variable is 0.68 . These results indicate when a company experiences an increase in sales growth, the company's tendency to act aggressively in financial and tax reporting will simultaneously increase by $68 \%$. This indicates that companies that experience sales growth tend to engage in a low complementary level of financial and tax aggressiveness. This result is in accordance with previous research, where companies with sales growth tend to conduct tax aggressiveness to minimize taxes paid (Wahyuni et al., 2019) and aggressiveness in financial reporting to show asset growth to investors (Prasetya and Gayatri, 2016) and maintain the firm's sales growth (Rachmawati et al., 2019).

\section{Conclusion}

This research considers the costs and benefits the company will face if they carry out financial and tax aggressiveness at the same time. Audit quality has a negative and significant effect on the complementary level of financial and tax aggressiveness (COMP $\mathrm{it}_{\mathrm{it}}$. When the firm has good audit quality, the risks faced by the firm will also be higher so that the complementary level of financial and tax aggressiveness tends to be low. This result is in accordance with the research of Herusetya (2012), Sandy and Lukviarman (2015), and Feranika et al. (2016). Financial constraints is a positive and significant effect on the complementary level of financial and tax aggressiveness $\left(\mathrm{COMP}_{\mathrm{it}}\right)$. Firms that experience financial constraints tend to engage in a high complementary level of financial and tax aggressiveness because the company will get benefits when conducting the financial and tax aggressiveness at the same time. This is in accordance with the research of Rachmawati et al, (2019).

This research is expected to make a positive contribution to all parties, especially those who are involved in the research namely investors, regulators, and managers who face the direct impact of the financial and tax aggressiveness. Firms are expected to consider decisions when undertaking aggressiveness in financial and tax reporting, as well as paying attention to the risks they will face such as being subject to sanctions by regulators and losing the reputation if the act of financial and tax aggressiveness are revealed. Investors and potential investors are expected to be more careful and make the right decisions when investing in companies that experience financial constraints and have low audit quality because these companies tend to engage in complementary level of financial and tax aggressiveness. Regulators are expected to strengthen their regulations related to financial and tax aggressiveness so there are no loopholes for companies to carry out these two act. Finally, Big Four and non-Big Four audit firms are to maintain their independence, integrity and transparency to produce a good audit quality.

From the results, there are several suggestions for further research. This study is still limited to one industrial sector company listed on the Indonesia Stock Exchange (IDX) so the results cannot be generalized to other industrial sectors. The research period only lasts from 2017-2019, this research only focuses on 2 factors to determine the complementary level of financial and tax aggressiveness. Finally the audit quality is only measured by the size of audit firms. We suggest for further research can add other sectors to the research sample and increase the range of observation periods so that the results are more accurate and can be generalized to other industries. The addition of other variables that affect the complementary level of financial and tax aggressiveness, such as risk preference, book-tax conformity, and good corporate governance. The final suggestion for further research is to use other proxies to measure audit quality such as audit firm industry specialization or audit tenure.

\section{References}

Agatha, G. C., \& Nugraha, A. P. (2016). Analisis Pelaporan Keuangan Agresif dan Agresivitas Pelaporan Pajak. Jurnal Ilmiah Mahasiswa FEB Universitas Brawijaya, 5(1).

Alkausar, B., Lasmana, M. S., \& Soemarsono, P. N. (2020). Agresivitas Pajak: Sebuah Meta Analisis dalam Persepektif Agency Theory. The International Journal of Applied Business Tijab, 4 (1), 52-62.

Amaliyah, R., \& Rachmawati, N. A. (2019). Peran Komisaris Independen Dan Kualitas Audit Terhadap Penghindaran Pajak. 1(01). Annisa, N. A., \& Kurniasih, L. (2012). Pengaruh Corporate Governance Terhadap Tax Avoidance. Jurnal Akuntansi \& Auditing, $8(2), 95-189$. 
Budiman, J., \& Setiyono. (2012). Pengaruh Karakter Eksekutif terhadap Penghindaran Pajak (Tax Avoidance).

Chen, C., \& Lai, S. (2012). Financial Constraint and Tax Aggressiveness. Journal of Financial Economics, 1-41.

Chen, S., Chen, X., Cheng, Q., \& Shevlin, T. (2010). Are family firms more tax aggressive than non-family firms? Journal of Financial Economics, 95(3), 488-511.

Christiani, I., \& Nugrahanti, Y. W. (2014). Pengaruh Kualitas Audit Terhadap Manajemen Laba. Jurnal Akuntansi dan Keuangan, 16(1), 52-62. https://doi.org/10.9744/jak.16.1.52-62

Dewi, N. N., \& Jati, I. K. (2014). Pengaruh Karakter Eksekutif, Karakteristik Perusahaan, dan Dimensi Tata Kelola Perusahaan yang Baik pada Tax Avoidance di Bursa Efek Indonesia. E-Jurnal Akuntansi Universitas Udayana, 6(2), 249-260.

Fadhilah, R. (2014). Pengaruh Good Corporate Governance Terhadap Tax Avoidance (Studi Empiris Pada Perusahaan Manufaktur yang Terdaftar di BEI 2009-2011). Jurnal Akuntansi, 2(1).

Feranika, A., Mukhzarudfa, \& L, T. A. (2016). Pengaruh Kepemilikan Institusional, Dewan Komisaris Independen, Kualitas Audit, Komite Audit, Karakter Eksekutif, dan Leverage Terhadap Tax Avoidance (Studi Empiris Pada Perusahaan Manufaktur di Bursa Efek Indonesia dengan Tahun Pengamatan 2010-2014). Jurnal Akuntansi \& Keuangan Unja, 1(4). https://doi.org/10.22437/jaku.v1i4.3180

Fernandes, A., Cerqueira, A., \& Brandão, E. (2017). Tax and Financial Reporting Aggressiveness: Evidence from Europe.

Firmansyah, A., \& Bayuaji, R. (2019). Financial Constraints, Investment Opportunity Set, Financial Reporting Aggressiveness, Tax Aggressiveness: Evidence From Indonesia Manufacturing Companies. Academy of Accounting and Financial Studies Journal, 23(5), 1-18.

Frank, M. M., Lynch, L., \& Rego, S. O. (2009). Tax Reporting Aggressiveness and Its Relation to Aggressive Financial Reporting. The Accounting Review, 84(2), 467-496. https://doi.org/10.2308/accr.2009.84.2.467

Hanafi, U., \& Harto, P. (2014). Analisis Pengaruh Kompensasi Eksekutif, Kepemilikan Saham Eksekutif dan Preferensi Risiko, Eksekutif Terhadap Penghindaran Pajak Perusahaan. Diponegoro Journal of Accounting, 3(2), 1162-1172. From https://ejournal3.undip.ac.id/index.php/accounting/article/view/6180

Hanna, \& Haryanto, M. (2016). Agresivitas Keuangan, Aresivitas Pajak, Tata Kelola Perusahaan dan Kepemilikan Keluarga. Jurnal Akuntansi, 20(03), 409-419.

Hantono. (2016). Pengaruh Ukuran Perusahaan, Total Hutang, Current Ratio, Terhadap Kinerja Keuangan dan Harga Saham Sebagai Variabel Moderating. Jurnal Wira Ekonomi Mikroskil, 6(1).

Hanum, H. R., \& Zulaikha. (2013). Pengaruh Karakteristik Corporate Governance Terhadap Effective Tax Rate (Studi Empiris Pada Bumn Yang Terdaftar Di BEI 2009-2011). Diponegoro Journal of Accounting, 0, 201-210. From https://ejournal3.undip.ac.id/index.php/accounting/article/view/3272

Herusetya, A. (2012). Analisis Kualitas Audit Terhadap Manajemen Laba Akuntansi: Studi Pendekatan Composite Measure Versus Conventional Measure. Jurnal Akuntansi dan Keuangan Indonesia, 9(2), 117-135. http://dx.doi.org/10.21002/jaki.2012.08

Kamila, P. A. (2014). Analisis Hubungan Agresivitas Pelaporan Keuangan dan Agresivitas Pajak. Jurnal Keuangan dan Perbankan, 16(2). From http://journal.perbanas.id/index.php/jkp/article/view/197

Koh, Y., \& Lee, H.A. (2015). The effect of financial factors on firms' financial and tax reporting decisions. Asian Review of Accounting, 23(2), 110-138. doi:10.1108/ARA-01-2014-0016

Kurniasih, B. B., \& Sri, S. (2012). Pengaruh Ukuran Perusahaan, Profitabilitas, Leverage, Dan Kepemilikan Institusional terhadap Perataan Laba: Studi Empiris pada Perusahaan Food and Beverages yang Terdaftar di BEI. Dinamika Akuntansi Keuangan Dan Perbankan, 1(2), 143-158. From https://www.unisbank.ac.id/ojs/index.php/fe9/article/view/1593

Leksono, A. W., Albertus, S. S., \& Vhalery, R. (2019). Pengaruh Ukuran Perusahaan dan Profitabilitas terhadap Agresivitas Pajak pada Perusahaan Manufaktur yang Listing di BEI Periode Tahun 2013-2017. 5(4), 301-314. http://dx.doi.org/10.30998/jabe.v5i4.4174

Lennox, C. S., Lisowsky, P., \& Pittman, J. (2013). Tax Aggressiveness and Accounting Fraud. Journal of Accounting Research, 51(4), 739-778. http://dx.doi.org/10

Mardiyaningsih, M. (2020). Pengaruh Komisaris Independen, Komite Audit, Kualitas Audit Terhadap Nilai Perusahan (Studi Empiris Perusahaan Perbankan yang Terdaftar di Bursa Efek Indonesia Tahun 2015-2019).

Negara, I. K. (2019). Analisis Pengaruh Kebijakan Dividen dan Leverage Terhadap Nilai Perusahaan dengan Agency Cost Sebagai Variabel Intervening pada Emiten Manufaktur Sektor Industri Barang Konsumsi yang Terdaftar di Bursa Efek Indonesia. Jurnal Riset Manajemen, 19(1), 49-66. https://doi.org/10.29303/jrm.v19i1.37

Nyoman Yudha Astriayu Widyari, N. K. (2019). Pengaruh Kualitas Audit, Size, Leverage, dan Kepemilikan Keluarga pada Agresivitas Pajak. E-Jurnal Akuntansi , 27(1). https://doi.org/10.24843/EJA.2019.v27.i01.p15

Prasetya, P. J., \& Gayatri, G. (2016). Pengaruh Ukuran Perusahaan terhadap Manajemen Laba dengan Pengungkapan Corporate Social Responsibility Sebagai Variabel Intervening. E-Jurnal Akuntansi, 14(1), 511-538. From https://ojs.unud.ac.id/index.php/Akuntansi/article/view/17482

Rachmawati, N. A., Utama, S., Martani, D., \& Wardhani, R. (2019). Determinants of the complementary level of financial and tax aggressiveness: a cross-country study. Int. J. Managerial and Financial Accounting, 11(2), 145-166.

Rachmawati, N. A., Utama, S., Martani, D., \& Wardhani, R. (2020). Do country characteristics affect the complementary level of financial and tax aggressiveness? Asian Academy of Management Journal of Accounting and Finance, 16(1), 45-62. https://doi.org/10.21315/aamjaf2020.16.1.3 
Rosidy, D., \& Nugroho, R. (2019). Pengaruh Komisaris Independen Dan Kompensasi Eksekutif Terhadap Agresivitas Pajak. Jurnal Info Artha, 3(1), 55-65.

Rusmin, R. (2010). Auditor quality and earnings management: Singaporean evidence. Managerial Auditing Journal, 25(7), 618-638. https://doi.org/10.1108/02686901011061324

Sandy, S., \& Lukviarman, N. (2015). Pengaruh Corporate Governance Terhadap Tax Avoidance: Studi Empiris pada Perusahaan Manufaktur. Jurnal Akuntansi dan Auditing Indonesia, 19(2), 85-98. https://doi.org/10.20885/jaai.vol19.iss2.art1

Sanjaya, F. B. (2017). Pengaruh Auditor Spesialisasi Industri, Ukuran KAP, Audit Tenure, Kepemilikan Keluarga, dan Kualitas Laba Terhadap Cost of Equity. Jurnal Akuntansi Bisnis, 15(2). https://doi.org/10.24167/jab.v16i1.1366

Shavira, H., Akram, \& Bambang. (2017). Analisis Agresivitas Pelaporan Keuangan, Agresivitas Pajak. Jurnal Riset Akuntansi Aksioma, 16(1), 079-109. https://doi.org/10.29303/aksioma.v16i1.35

Sugandi, R. R., \& Prawira, I. F. (2019). Pengaruh Agresivitas Pelaporan Keuangan Terhadap Agresivitas Pajak: Dampak Penerapan Mandatory Disclosure Rules (Studi Pada Negara-Negara Anggota G-20). Organum Jurnal Saintifik Manajemen dan Akuntansi , 2(1), 12-24. https://doi.org/10.35138/organum.v2i1.55

Swingly, C., \& Sukartha, I. M. (2015). Pengaruh Karakter Eksekutif, Komite Audit, Ukuran Perusahaan, Leverage dan Sales Growth Pada Tax Avoidance. E-Jurnal Akuntansi, 10(1), 47-62. From https://ojs.unud.ac.id/index.php/Akuntansi/article/view/9863

Wahyuni, L., Fahada, R., \& Atmaja, B. (2017). The Effect of Business Strategy, Leverage, Profitability and Sales Growth On Tax Avoidance. Indonesian Management and Accounting Research, 16(2). http://dx.doi.org/10.25105/imar.v16i2.4686

Weisbach, D. A. (2014). Distributionally Weighted Cost-Benefit Analysis: Welfare Economics Meets Organizational Design. Journal of Legal Analysis, 7(1), 151-182. https://doi.org/10.2139/ssrn.2450142

Publisher's Note: SSBFNET stays neutral with regard to jurisdictional claims in published maps and institutional affiliations.

\section{(a) (1)}

() 2021 by the authors. Licensee SSBFNET, Istanbul, Turkey. This article is an open access article distributed under the terms and conditions of the Creative Commons Attribution (CC BY) license (http://creativecommons.org/licenses/by/4.0/).

International Journal of Research in Business and Social Science (2147-4478) by SSBFNET is licensed under a Creative Commons Attribution 4.0 International License. 